\title{
Interrelation Between Fertility And Female Labor Force In Korea
}

Namchul Lee, Korea Research Institute for Vocational Education \& Training, Korea Ji-Sun Chung, Korea Research Institute for Vocational Education \& Training, Korea

\begin{abstract}
The aim of this paper is to understand recent economic observations, female labor force participation, and fertility in Korea drawing on various aggregate data. More detailed attention is then given to issues concerning the changing composition of fertility and labor force participation. This paper presents a review of available data on the role played by economy, labor force participation, and fertility. Fertility stands as a critical factor in females' efforts to improve their labor force. We analyze the effect of fertility on female labor force participation in Korea using the data from the government survey. Fertility is negatively related to labor force participation in Korea.
\end{abstract}

Keywords: Labor force participation, Fertility, Knowledge-based economy

\section{INTRODUCTION}

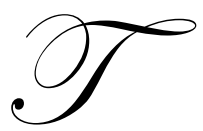

he Korea's successful industrial growth began in the early 1960s, when the government instituted sweeping economic reforms emphasizing exports and labor-intensive light industries. The Korea government also carried out currency reform, strengthened financial institutions, and introduced flexible economic planning. Korea's rapid and sustained development can be ascribed to a peculiar combination of social, economic factors, and the high level of industry.

Recently Korea is shifting from a manufacturing-based economy to one that overwhelmingly provides service and information. Korea economies are becoming "knowledge-based,"1 where the creation, distribution, and use of information and knowledge-including both technology and human capital- are becoming increasingly important. It has been encountering very tough obstacles in the knowledge-based economy. The Korean economy has been transforming from manufacturing industry to a knowledge-based economy, owing to the continuous development of new one based predominantly on the technology, especially information and communication technology. Female labor force participation is lowest in developing countries that are dominated by a manufacturing sector and low levels of women education compared with male. While female labor force participation rates are high in developed countries with large service sectors and highly educated female.

Mammen and Paxson (2000) find the relationship between female labor participation rates and per capita income to be U-shaped. Female labor force participation depends on the fertility rate, the wage rate, and intra-family transfer. Fertility is a key development strategy aimed at increasing female labor force. Total fertility rate of Korea decreased from 5.6 children women in 1962 to 1.08 in 2005. The reduction in fertility and increase in labor supply per capita may help explain this apparent economic growth miracle. Increased female labor supply may raise the economic returns to women schooling, providing positive incentives for female to invest in education. However, low fertility has proven to be an especially difficult area for women to increase labor force. As for recent fertility decline

\footnotetext{
${ }^{1}$ In 2000, Korea launched a national strategy for its transition toward a knowledge-based economy, which was aimed at overcoming the after-effects of the 1997 financial crisis and helping Korea cope with the demands of the new millennium-the need to become a more competitive and advanced knowledge-based economy in an environment where survival is increasingly linked to the information revolution.
} 
in Korea, there has also been various empirical analysis. Cho (2006), Lee(2005), Kim (2006) made time-series analysis about the effects of various factors on fertility. Many researchers have explained the mechanism of lowering fertility in Korea by economic factors and demographic factors, family value factors.

In this paper, we analyze changes in Korean economy and in the structure of woman's labor force participation and fertility rate in terms of economic factors in Korea. The analysis is based on micro-data from the economically active population survey and population \& housing census of Korea National Statistical Office (hereafter NSO). In this paper, we aim to contribute to the reviewing literature and statistical data on this topic by studying changes over time female labor force and fertility. One contribution of this paper is to provide on the basis of annual updates, to identify trends of implemented policies in the field of labor market population policy. Also, this paper is to become a working tool for analysis and policy-making in the field of labor market and economy.

The paper is organized as follows. Section II examines the Korean economy under the knowledge-based economy. Section III discusses the relationship between fertility and female labor force. Fertility keys to understanding changes in labor force participation over time, particularly, among female workers. Section IV investigates the changes in labor force participation in terms of females and males. Section $\mathrm{V}$ presents conclusions in this article.

\section{KNOWLEDGE-BASED ECONOMY IN KOREA}

In Korea, GDP per capita increased by more than fifteen times between 1970 and 1997, from U.S\$ 650 to U.S\$ 10,371. However, the Korea economy slipped after the financial crisis in 1997. GDP per capita dropped to US\$ 6,864 in 1998. It is estimated that the national competitiveness keeps slackening and many concerned voices are being heard that the economic hardship may not be overcome within a short period of time. However, GDP per capita increased to US\$ 9,822, US\$14,148, and US\$18,372 in 2000, in 2004, and in 2006, respectively.

Since the 1960s, the growth of the Korean economy has been driven by several industries. The 1970s were driven by labor-intensive light industries, the 1980s by capital-intensive heavy and chemical industries, and the 1990s by high-tech assembly industries. Although unemployment rates have been higher among male workers than females since the economic crisis, the employment level for female workers declined more rapidly than that of male workers. From the beginning of the 1990s, the Korean society became more open and democratized, and for the first time, a civil government came into power. The system of the higher education needed to change to accommodate new values and practices of the society. In the 21 st century, high technology information and communication industries, and sophisticated service industries will make up a core section of the economy, which means that society, overall, will become more knowledge and information centered. In the case of OECD countries, the industries that are based on knowledge and technology showed a rapid growth during 1985 1994. In addition, the proportion of a value-added industry already stood above 50 percent in 1997.

A study of employment and its changes in the industrial structure will enable us to understand the changes in Korean economic structure and the demand shift of labor market industries. In 1960, agriculture and fisheries industries accounted for 36.8 percent of nominal GDP, while the mining and manufacturing industries accounted for 20.0 percent and service industry was 43.2 percent of the GDP. However, in 2006, the ratio of agriculture and fisheries employment was reduced to 7.7 percent, while the manufacturing and service industries increased to 18.0 percent and 74.2 percent, respectively (NSO, 2006). Employment in the primary and manufacturing sectors decreased by 7.9 percent and 18.6 percent, respectively in 2005, while service sector employment increased 73.5 percent during the same period. Total employment in the manufacturing has constantly declined since 1990. In contrast, employment in the service sector has continued to grow, although it has slowed somewhat in recent years.

However, within industrial sectors, knowledge-based industry sectors perform well above other sectors in terms of job creation (NSO, 2005). Korea is shifting a manufacturing-based economy to a service/technology-based economy. 
One of the noticeable changes between pre (1997) and post (1998) economic crisis periods was acutely increasing unemployment rates from 2.6 percent to 6.8 percent. This increase was more dramatic among males, from 2.8 percent to 7.6 percent, than among females, from 2.3 percent to 5.6 percent during the same period. One can argue that although unemployment rates were higher among male workers, female workers also suffered considerably (NSO, Various years).

While Korea has achieved remarkable economic growth during the last three decades, ${ }^{2}$ progress toward improving the status of women has been less impressive. This is basically due to discrimination against women, which stems from a deeply rooted Confucian male-oriented cultural tradition and patriarchal family system. The industrial sector in Korea has served as the main engine for creating per capita income and has grown into a sound, transparent sector through a series of stringent restructuring measures in the aftermath of the 1997 financial crisis. The world economy is rapidly changing with the emergence of the new paradigm. There has arisen the knowledgebased society in an environment of globally networked economy. ${ }^{3}$ In the $21^{\text {st }}$ century, the picture of a new era, fundamentally different from the industrial society, is emerging. Digital globalization is rapidly progressing and the knowledge-based economy is arriving. Accordingly, the foundation of national, organizational, and personal development is being transformed from physical resources to human resources. In many developing countries including Korea, the problems of low skills and low trust, along with industrial structures founded on low valueadded industries, which is the legacy of the industrialization era, are blocking the advent of the knowledge-based economy.

In Korea, it is expected that an industry based on knowledge and a service sector related to information technology will play an important role in creating job opportunities in the future. Meanwhile, it is also expected that the size of the industry relying on labor force and financial investment will decrease. In Korea, prior to the IMF bailout, the pattern of employment was static, which meant that once employed, employees generally worked in the same workplace until their retirement. However, this trend has changed. Higher education has contributed greatly to constructing the foundation of economic growth via the development of human resources. OECD reports that the Korean economic growth is attributed to the successful investment in human resources (OECD, 1996). The successful investment in human resources originates from a zeal for education in Korea ${ }^{4}$ and also results from the implementation of efficient policies regarding the development of human resources by the government.

The governmental policies on the development of human resources have changed with the pursuit of different goals for industrial policies in the plan the economic development. In other words, in each stage of industrialization in Korea, the systems for education and human resources training have changed in order to meet the steady demand for labor necessary for economic development. Therefore, in terms for quantitative indices, the structure of human resources in Korea has advanced as much as that of industrialized countries. As structures of knowledge and technology are becoming more complicated and specialized with the advent of the knowledge-based economy, there is an increasing need for individuals, enterprises and nations to adapt to, and to lead these changes.

\footnotetext{
2 The gross domestic product (GDP) grew 2 billion dollars in 1960 to 398 billion dollars in 1998. In 1999, the Korean economy has recovered greatly from recessions started at the end of 1997, recording more 10 percent growth.

3 According to the World Bank, the features of the knowledge-based economy are as follows. First, knowledge is being developed and applied in new ways. The information revolution has expanded networks and provided new opportunities for access to information. It has also created new opportunities for generating and transferring information. Second, product cycles are shorter and the need for innovation greater. Third, trade is increasing worldwide, increasing competitive demands on producers. Fourth, small and medium-size enterprises in the service sector have become increasingly important players, in terms of both economic growth and employment.

${ }^{4}$ In 1985, almost all students of middle school age attended school, and their promotion rate to high school indicated $90 \%$ in 1995. Of the total population, the rate of the participation in tertiary education, among the groups aged 18 to 21 and 22 to 25 , revealed $40.7 \%$ and $17.4 \%$, respectively. These figures stand above the average, which is $23.2 \%$ and $16.9 \%$, respectively (OECD Education at a Glance, 1998).
} 
In the 21 st century knowledge-based society, national competency is influenced by educational competency. For national human resources development based growth, a fundamental innovation in higher education is necessary. ${ }^{5}$

In the era of knowledge-based economies, there is a need for universities to play a central role in fostering research manpower for the creation of national competency, fostering technical manpower that matches the demands of industries and in disseminating knowledge. In order to lift national competency, universities should uplift their ability to cooperate with enterprises as well as improve the quality of university education. National competency refers to the ability of a nation to provide a business environment that could continuously elevate the competency of enterprises. While there are various input factors and systematic conditions that raise the competency of enterprises, the most important factor would be for universities to provide a plenty of creative manpower by dramatically lowering the cost of knowledge.

\section{THE RELATIONSHIP BETWEEN FERTILITY AND FEMALE LABOR FORCE}

Economists have been interested in the question of why fertility rates always decline when a country goes through the process of sustained development. The traditional allocation of time provides a conceptual framework suggests that in industrialized countries, in particular, fertility and female labor force participation will likely be inversely related (Shapiro and Shaw, 1983). Empirical studies employing cross-countries data discuss the possibility that the emergence of high and persistent rates of unemployment in Europe might have been responsible for the reversal in the sign of the correlation between fertility and participation (Anh and Mira, 2002).

However, Becker and Lewis (1974) and Willis (1973) have provided explanations of this phenomenon from different perspectives. They use the concept of the household production function, focusing on the importance of time as an input in household production processes and the relevance of the quantity and quality of childbirth and childcare facilities in the fertility decision. Easterlin and Crimmins (1985) explained urbanization and industrialization as the factors responsible for the decline in desired fertility. We suggest that fertility decline is culture-specific in countries and many factors affect fertility such as preferences and the desired number of children. Especially, education and economic activity are commonly considered as two of the main determinants of fertility decline and demographic transition. Korea has experienced a remarkably rapid fertility decline in recent years.

During the period 1961-95, Korea experienced the biggest change in the fertility rate. While fertility has been declining in less development countries, there has been a rapid narrowing of the gap in mortality rates between developed countries (World Bank, 2003). There are several factors for the decline in fertility rates. The primary reason is undoubtedly the improvement in health conditions through the Third World. The second factor is the greater number and reliability of contraceptive devices, as well as greater social acceptance of family planning. A third factor that has been given much attention by economists is the growing "price" of children. The price or cost of a child for the family is the direct cost of education, clothing, food, and opportunity cost of the wife's time if she does not work. The relative price of time-intensive activities such as raising children has grown considerably, causing families to consciously cut back on the number of children they desire.

In Korea, the birth rate has been falling rapidly over the last few decades to a level similar to that of the developed countries from 6.0 per fertile woman in 1960 to 1.13 per fertile woman in 2006. This low birth rate means married women will spend less time on child care, increasing their likelihood of participation in the labor force. It has facilitated growth in the participation of married women in the labor force by providing substitutes for the wife's time at home, and it has lowered the costs of fertility control. In this context, then both the secular decline in fertility and the secular increase in the labor force attachment of married women in Korea are seen as consequences of increased real wages and market work opportunities available to women. However, the low fertility has brought

\footnotetext{
5 The promotion rate of higher education has increased from $32.8 \%$ in 1980 to $66.2 \%$ in 1999 . However, the number of prospective students entering university still outnumbers those who receive admission (its ratio is $77 \%$ in 1999). Furthermore, the number of graduate students has increased; thus, it is anticipated that higher education will become popularized (Ministry of Education, 1997).
} 
about a lot of problems such as population aging, labor force shortage, and unbalance of sex ratio. Confronting with new population problems, Korea government changed the policy of family planning project from the quantitative control of population to the qualitative consideration of population.

On the other hand, the decline in the birth rate has changed the age composition of the population. More specifically, the proportion of the population younger than 15 years has decreased dramatically. As a whole, the female number of the population younger than 15 years changed from 24.8 percent (5,356 thousand) in 1990 to 18.1 percent $(4,279$ thousand) by 2006 (NSO, 1999; 2006). Females in developing countries are faced with competing demands of reproduction and workforce roles. The relationship between work and fertility is complex. Female workers may choose to limit childbearing so they can work and earn income, as having a child may affect the type of work they can do, where they can work or the hours they can work. Higher wages are associated with lower fertility rates. More-educated women who can command relatively high wage rates in the labor market tend to have fewer children than less-educated women for whom wages are low. Child rearing is a highly intensive activity, and thus the opportunity cost of children-the income sacrificed by not being in the labor market-is higher for more educated women than for those who are less- educated.

Results indicate remarkable improvement in the level of education of women and a clearly negative correlation between women's education and fertility. A negative relationship between women's labor force participation and fertility can be expected on both sociological and economic grounds. From a sociological perspective, women's participation in the labor market is seen as inconsistent with their traditional role as mothers and homemakers. The economic conceptualization of the relationship between women's employment and fertility emphasizes the opportunity cost of children.

According to this perspective, as the opportunity cost of children increases due to increased employment opportunities for women fertility will decrease. To the extent that role incompatibility may be viewed as related to rising opportunity costs, the sociological and economic perspectives are quite consistent.

Industries countries that experienced significant fertility declines between 1961 and 1996. While fertility has been declining in LDCs, there has been a rapid narrowing of the gap in mortality rates between developed countries. The primary reason is undoubtedly the improvement in health conditions through out the Third World (UN, 1996). Mincer (1962) and Becker (1965) imply that an increase in real wages induces women to allocate more time into the labor market and decrease non-market activities such as home production and child bearing. This theory thus implies a negative association between fertility rates and female employment ratio, which is consistent with the secular trends of fertility rates and female employment ratios among developed countries.

The traditional allocation of time provides a conceptual framework that suggests that in industrialized countries in particular fertility and female labor force participation will likely be inversely related facts. Todaro (1996) explains that a 50 percent fall in LDC fertility rates by 2000 will reduce the male labor force by only 13 percent by the 2015, a reduction from about 1.39 to 1.21 billion workers. Also, the theory implies that the two activities will be jointly determined, in the sense that potential earnings (the wage rate) and employment possibilities in the labor market will influence decisions about childbearing and about participation in the labor market. Female in developing countries are faced with competing demands of reproduction and workforce roles. The relationship between work and fertility is complex. Working female may choose to limit childbearing so they can work and earn income, or affect type of work, place of work or hours. 
Table 1: Total Fertility Rates and Female Labor Participation Rates in Korea, 1980-2006

\begin{tabular}{|l|c|c|c|c|c|c|c|c|c|}
\hline (Unit: percent) \\
\hline Year & 1980 & 1985 & 1990 & 1995 & 2000 & 2005 & 2006 & Change \\
\hline Fertility & 2.83 & 1.67 & 1.59 & 1.65 & 1.47 & 1.08 & 1.13 & -1.70 \\
\hline Participation & 42.8 & 41.9 & 47.0 & 48.3 & 48,4 & 50.0 & 50.2 & 7.4 \\
\hline
\end{tabular}

Source: National Statistical Office, Annual Report on the Vital Statistics (various years).

<Table 1> indicates total fertility rates and labor force participation from 1980 to 2006 in Korea. In Korea, the birth rate has been falling rapidly over the last few decades to a level similar to that of the developed countries from 6.0 per fertile woman in 1960 to 1.13 per fertile in 2006. This low birth rate means married women will spend less time on child care, increasing their likelihood of participation in the labor force. It has facilitated growth in married women's labor force participation by providing substitutes for the wife's time at home, and it has lowered the costs of fertilities control. In this context, then both the secular decline in fertility and the secular increase in the labor force attachment of married women in the Korea are seen as consequences of increased real wages and market work opportunities available to women.

The decline of fertility can affect economic factors such as women labor market participation, household income, or male income. What exactly is behind Korea's low birth rate? Across the developed countries, as a general trend, women are working more and marrying later. But compare Korea with Sweden, for example, more Swedish women work and they marry later, yet the country's birth rate is far healthier. So Korea's troubles cannot be attributed to these two factors alone. In Korea, people flagged up three separate issues as obstacles to child-rearing, money worries, the problems of working, and having a family, and a lack of support for mothers. Pay is often linked to age, while a disproportionate number of young people and women are employed on poorly-paid temporary contracts. Child allowances are low, while housing and education costs are high. The financial situation for young couples can be even harder because many women give up work when they have children. Some workplaces are unwilling to keep jobs open for mothers-to-be, who can come under both direct and indirect pressure to leave. For those women who do return to work, things can be hard.

Many struggle to find affordable child care facilities that can keep infants all day. Others discover that although they have jobs, they bear no resemblance to the ones they left and promotion is no longer a possibility. Many women want to work and have kids. But it's still the case that it is either work or kids. $\langle$ Table 2$\rangle$ shows that the opinions toward obstruction of female employment in Korea.

Table 2: Opinions toward obstruction of female employment

\begin{tabular}{|c|c|c|c|c|c|c|c|c|}
\hline & $\begin{array}{c}\text { Lack of } \\
\text { ability }\end{array}$ & $\begin{array}{c}\text { Social } \\
\text { prejudice }\end{array}$ & $\begin{array}{c}\text { Lack of } \\
\text { responsibility }\end{array}$ & $\begin{array}{c}\text { Working } \\
\text { conditions }\end{array}$ & $\begin{array}{c}\text { Job } \\
\text { offering }\end{array}$ & $\begin{array}{c}\text { Infant } \\
\text { rearing }\end{array}$ & $\begin{array}{c}\text { House } \\
\text { work }\end{array}$ & Others \\
\hline $\mathbf{2 0 0 2}$ & 2.0 & 21.7 & 4.5 & 13.2 & 2.4 & 41.1 & 9.2 & 5.9 \\
\hline $\mathbf{2 0 0 6}$ & 1.7 & 17.4 & 2.9 & 12.6 & 3.2 & 47.0 & 7.4 & 6.9 \\
\hline Change & -0.3 & -4.3 & -1.6 & -0.6 & 0.8 & 5.9 & -1.8 & -1.0 \\
\hline
\end{tabular}

Source: National Statistical Office (2006), Social Statistics Survey.

As we can see the <Table 2>, the proportion of obstruction of female employment was 47.0 percent of the participation of raising children. 17.4 percent of the social prejudges and 12.6 percent of the working conditions in 2006. According to survey in 2006, married men only spent about 30 minutes each day on household tasks or with their children. This is partly down to traditional attitudes. Korea men tend not to cook, clean or change nappies. But 
another problem is a culture of long working hours, followed by compulsory after-work socializing. Sam Sung Economic Research Institute in Korea analyses reasons about low fertility after in IMF by using following equation:

$Y=\alpha+\beta_{1}(C)+\beta_{2}(I)+\beta_{3}(S)+\beta_{4}(V)+\varepsilon$

where $Y$ is the birth rate level, $C$ is child factors, $I$ is income factor,,$S$ is social and work place factor, $V$ is the value factor, and $\varepsilon$ is error term. By using this equation, <Table 3> shows that the regression results of low fertility. In $<$ Table 3>, social and work place factors $(-0.181)$ have strong effect on fertility, and then child factor (-0.122), income factor (-0.113), and value factor (-0.053), respectively.

Table 3: The regression results of low fertility

\begin{tabular}{|c|c|c|c|c|}
\hline Independent variable & Estimation & Standard error & t- value & P-value \\
\hline Intercept & $1.480^{* * *}$ & 0.019 & 79.51 & $<0.0001$ \\
\hline C & $-0.122^{* *}$ & 0.051 & -2.39 & 0.044 \\
\hline I & $-0.113^{*}$ & 0.059 & -1.92 & 0.091 \\
\hline S & $-0.181 * *$ & 0.071 & -2.56 & 0.034 \\
\hline V & -0.053 & 0.033 & -1.63 & 0.143 \\
\hline
\end{tabular}

Note: $*, * *, * * *$, significant level, 10 percent, 5 percent, 1 percent, respectively.

$<$ Table 4> shows a correlation matrix in three OECD countries during the 1960-2002. According to OECD panel data, the female economic activity and fertility is negative effect. OECD member countries the relationship between fertility and female economic activity rate is -0.522 , significant statistically at 1 percent level from 1960 to 2002. The correlation between the increase in GDP and the percent of female part-time workers is negative. Even though consider the characteristics of each country and time-series, theses results do not change in fixed effect model and random effect model.

Table 4: A correlation matrix

\begin{tabular}{|c|c|c|c|c|}
\hline & Fertility rate & Per GDP per capita & $\begin{array}{c}\text { Female economic } \\
\text { activity rate }\end{array}$ & $\begin{array}{c}\text { Percent of female } \\
\text { part-time work }\end{array}$ \\
\hline Fertility rate & 1 & & & \\
\hline GDP per capita & -0.522 & 0.509 & 1 & \\
\hline $\begin{array}{c}\text { Female economic activity } \\
\text { rate }\end{array}$ & -0.486 & 0.331 & 0.319 & 1 \\
\hline $\begin{array}{c}\text { Percent of female part- } \\
\text { time work }\end{array}$ & 0.111 & & \\
\hline
\end{tabular}

Source: World Development Indicators (World Bank) \& OECD Labor Statistics (Each Year). Note: 1) All correlation is significant at 1 percent level. 2) This case included three OECD countries during the 1960-2002.

<Table 5> lists eight countries which experienced significant declines between 1961 and 2005. Compared with 1961-1965 and 2000-2005, the total lifetime fertility of the average adult woman declined from 4.9 to 2.65 children. The fertility rate in Korea, has been falling rapidly over the last few decades to a level similar to that of the developed countries, from 5.4 per fertile woman in 1961-1965 to 1.72 per fertile in 2000-2005. Changes in fertility are probably contributed to the increase in female labor force participation. Clearly, socio-economic development has contributed to the fertility decline in the form of changes in attitudes toward promoting small-family norms and family planning. Also, it has facilitated growth in married women's labor force participation by providing substitutes 
for the wife's time at home, and women spend less time out of the labor market for child care.

Table 5: International Comparisons of the Fertility Rate(\%)

\begin{tabular}{|c|c|c|c|c|c|c|}
\hline Country & $\begin{array}{c}\mathbf{1 9 6 1 - 1 9 6 5} \\
(\mathbf{A})\end{array}$ & $\begin{array}{c}\mathbf{1 9 7 1 - 1 9 7 5} \\
(\mathbf{B})\end{array}$ & $\begin{array}{c}\mathbf{1 9 8 1 - 1 9 8 5} \\
(\mathbf{C})\end{array}$ & $\begin{array}{c}\mathbf{1 9 9 1 - 1 9 9 5} \\
(\mathbf{D})\end{array}$ & $\begin{array}{c}\mathbf{2 0 0 0 - 2 0 0 5} \\
(\mathbf{E})\end{array}$ & $\begin{array}{c}\text { Change rate } \\
(\mathbf{E}-\mathbf{A})\end{array}$ \\
\hline World & 4.9 & 4.5 & 3.6 & 3.1 & 2.65 & -2.25 \\
\hline Korea & 5.4 & 4.1 & 2.4 & 1.7 & 1.72 & -3.68 \\
\hline U. S & 3.3 & 2.0 & 1.8 & 2.1 & 2.06 & -1.24 \\
\hline U. K & 2.8 & 2.0 & 1.8 & 1.8 & 1.63 & -1.17 \\
\hline Hungary & 1.8 & 2.1 & 1.8 & 1.7 & 1.25 & -0.55 \\
\hline Norway & 2.9 & 2.3 & 1.7 & 1.9 & 1.85 & -1.05 \\
\hline Germany & 2.5 & 1.6 & 1.5 & 1.3 & 1.38 & -1.12 \\
\hline Australia & 3.3 & 2.5 & 1.9 & 1.9 & 1.79 & -1.51 \\
\hline Japan & 3.9 & 3.8 & 3.1 & 2.9 & 1.41 & -2.49 \\
\hline
\end{tabular}

Source: UN, World Population Prospects, 2006.

Note: Number of children per fertile female.

There has been a significant decline in the birthrate since the 1960s. This decline and the current preference for small families should be interpreted not as a separate factor "causing" an increase in women's labor force participation but as the result of a joint decision, confirming a preference shift away from household activities and toward market activities. Many without young children, however, remain in the labor force, thereby beginning a dramatic long-term increase in the labor force participation of women.

In the U. S. and Denmark, average hours of market work increased for women, mostly because more women were working, not because women worked more hours. ${ }^{6}$ In this context, then both the secular decline in fertility and the secular increase in the labor force attachment of married women in the industrialized countries are seen as consequences of increased real wages and market work opportunities available to women. Why the labor supply of married women has increased so dramatically since the mid-1970s. In recent decades, the greatest increases in labor force participation are for married women with very young children. For those with children under the age of two, for example, the labor force participation of married women at present has increased from 24 percent in 1970 to 54 percent in $1990 .^{7}$ Also, the labor force participation rates and hours of work of married women are related to changes in the husband's wage. A 10 percent increase in the husband's wage lowers the participation rate of women by 5.3 percentage points and reduces the hours that working wives allocate to the labor market by 1.7 percent. There is little evidence, however, that the husband's labor supply is affected by the wife's wage rate. ${ }^{8}$ The relationship between work and fertility is complex. Working females may choose to limit fertility so they can work and earn an income, or affect type, place and hours of work. Many empirical studies have found a strong negative relationship between number of children in the family and the probability of participation by the wife, but now is positive. ${ }^{9}$ That is, before the 1960 s, the higher a country female labor force participation, the lower their average fertility (e.g., Italy, Spain, and Greece); now countries with higher female labor

6 Thomas Juster and Frank Stafford, "The Allocation of Time, " Journal of Economic Literature 29: Table 3 (1991).

${ }^{7}$ Howard Hayghe, "Rise in Mother Labor Force Activity includes those with Infants," Monthly Labor Review, February: 43-45 (1986).

${ }^{8}$ Zabel, J. E, "The Relationship Between Hours of Work and Labor Force Participation in Four Models of Labor Supply Behavior," Journal of Labor Economics 11: 387-416 (1993).

9 See, for example, David Shapiro and Lois B. Shaw, "Growth in the Labor Force Attachment of Married Women: Accounting for Changes in the 1970s, ” Southern Economic Journal 50(2): p. 461-473 (1983). 
force participation also have higher rates of fertility (e.g., Sweden). Esping-Andersen (1999) found significantly negative (coefficient of -0.03) relationship between female labor force participation and fertility in 1960, found significantly positive (coefficient of 0.01) relationship between female labor force participation and fertility in 1992. Ahn and mira (2002) demonstrate that in 1980, the relationship between fertility and female labor force participation was significantly negative (coefficient of -0.44 ), while in 1989, the relationship was significantly positive (coefficient of 0.44).

\section{TRENDS IN LABOR FORCE PARTICIPATION}

One of the most important trends in Korea labor market in recent increases in female labor force participation. The percent of all women of 16 years and older in the labor force increased from 46 percent in 1970 to 50.1 percent in 2005. The labor force participation rates for women are not only higher than those for men at the aggregated level, but also at every age group. The trends in the rates for men and women are also different. In general, the rates for women have been rising, while the rates for men have been declining in 2005. Although labor force participation rates for specific groups change over time, the general overall pattern is fairly consistent across age groups and sexes. Labor force participation is relatively low for young persons (aged 15 to 19) because of school or child care responsibilities ${ }^{10}$. It rises during the working years, ages 20 to 59, and also increases over age over 60. The participation rate for persons aged 25 to 29 increased 10.3 percent; for those aged 30 to 39, the rate increased 2.1 percent; and for those aged over 60, the rate increased to 9.1 percent from 1980 to 2005. While the participation rate for persons aged 15-19 decreased 21.5 percent during the same period (NSO, 2006).

An analysis of participation rates conditional on age and education reveals that the upturn in the aggregate participation rate of women in ages 55-59 and over 60 is the result of positive behavioral and composition effects. The decrease in participation at young age (15-19 and 20-24 years old) due to increase in schooling. A large proportion of the decline in the participation rate of youth in the 1980s can be attributed to the long-term trend of increasing school enrollments. After financial crisis, labor force participation rates for women in 1999 were particularly low, compared with the rates in 1995. Between 1963 and 1999 there was a large and constant increase in participation rates of over 60 years olds women in Korea.

Despite the low status of women, their participation in economic activities has substantially increased over the past three decades. During the early stage of economic development, a large number of young female workers held jobs that required a minimum amount of skills such as in export-oriented, labor-intensive manufacturing industries. In addition, by 2005 almost half of all women aged 15 and over participated in economic activities, comprising 50.1 percent of the economically active population (NSO, 2005). However, the economic participation of women of child bearing and rearing ages remained unchanged due to two underlying factors.

The first was discrimination against women in the workforce, an instance of which is the widespread assumption that all women leave the workforce permanently once they are married. The other factor is due to limited institutional preparation for alternative child caring. Therefore, working women are most likely to be less educated or raised in families under economic hardship. Working women are relegated to the lowest paying jobs, limited in their job tenure and mobility, and receive lower wages compared to men, with the average wage for women being only 61.7 percent of that of men in 1998.

The labor force participation decision is based on a comparison of the market wage with the reservation wage. Thus, the increase in the labor force participation rates can be attributed not only to a rise in the market wage, but also to a decline in female reservation wages. The rise in the market wage, which increased female participation rates, also made childbearing a very expensive household activity. As a result, some of the causation runs in the opposite direction.

\footnotetext{
10 The middle school and high school enrollment ratio are 99.9 percent and 99.7 percent in 2005, respectively.
} 
A woman will participate in the labor market whenever her potential market wage $(\mathrm{W} t)$ exceed her reservation wage $(\mathrm{Wr})$. However, if this inequality is not satisfied, she will remain out of the labor force. Thus Wit > Wir at zero hours of work or equivalently. The probability that individual we will participate in the labor force, F $i$ equals the probability that the market wage exceeds the reservation wages: $\mathrm{F} i=\beta \mathrm{A} i-\delta \mathrm{B} i>\xi \mathrm{w} i-\xi \mathrm{r} i$. Since $\xi \mathrm{w} i$, and $\xi \mathrm{r} i$ are assumed to be two normally distributed random distributions with the mean at zero, one can define $\mathrm{M}=\xi \mathrm{r} i$ $\xi_{w} i$ and assume it to be normally distributed with zero and variance $\sigma 2$. The probability of participation in the labor force thus depends on: $F i=(\beta \mathrm{A} i-\delta \mathrm{B} i) / \sigma>(-\mathrm{V} / \sigma)$, where is the standard deviation of the error term. Using a probit procedure we can estimate the parameters $\beta \mathrm{A} i / \sigma$ and $\delta \mathrm{B} i / \sigma$. The participation equation $\mathrm{X}$ can be estimated either as a reduced-form equation where market wage and reservation wage are replaced by using a direct measurement of the market wage (Lee, 1999).

Women participate more not because they have fewer children, rather, they have fewer children because the rising wage induces them to reduce their time in the household sector and enter the labor market. Labor force participation of females is also influenced by technological changes in the process of household production. There have been remarkable time-saving technological advances in household production. As a result, the amount of time required to produce many household commodities has been cut drastically, freeing up spare time for leisure activities and for work in the labor market. The technological advances in household production probably reduced the gap in marginal need for specialization, and was less of a contributing factor to the increase in female labor force participation.

Female workers in the labor market constantly face sexual discrimination, such as restrictive recruitment practices, limited opportunities for promotion, unstable employment, and wage gaps between sexes. Although discrimination against working women still exists, these women have been slowly climbing the corporate ladder. In all aspects of women's economic activities, progress is slow but consistent. There is certainly a good deal of evidence to support the proposition that women are now entering the labor market with far better qualifications than their mothers and grandmothers had. The level of educational enrollment of women school-leaving age has been steadily improving over recent decades, to such an extent that in a number of countries they are now significantly better qualified than men on leaving school.

The labor force participation rates of women and men aged 15 to 19 never were as different as the rates of other age groups, reflecting even higher participation of young women, compared with other women and the lower participation of young men compared with other men. In 2005, the labor force participation rate for young women aged 15 to 19 was 10.3 percent. This rate was 62.6 percentage points lower than that for women 20 to 24 , also still 66.1 percentage points lower than the rates for women aged 25 to 29 . The labor force participation rates of women aged 15 to 19 decreased 24.1 percent from 1980 to 2005. While the largest increases in labor force participation rates among aged group was for those aged 25 to 29 . Remarkable changes in age-specific labor force participation rates for women occurred in Korea from 1980 to 2005, reflecting the significant change in women's role in the world of work over the past 26 years.

In <Table 6>, the main findings are follows. During the period 1985-2006, the female labor force participation rates of Korea increased substantially regardless of level of education (NSO). The female labor force participation rates at college or over level are higher than that at any other level of education during the same period. Before(1997) and after(1998) Korea's economic crisis, one of the most noticeable changes was the sharply decreasing female labor force participation rates from 61.0 percent to 56.7 percent for those with a college level or higher education. The male labor force participation rates at college level decreased from 91.8 percent to 90.6 percent during the same period. The male labor force participation rates show evidence that the economic crisis affected female workers more than male workers. The past 22 years have seen a dramatic change in the pattern of female participation in college or over by 18.1 percent. 
Table 6: Labor Force Participation Rates by Level of Education, 1985-2006

\begin{tabular}{|c|c|c|c|c|c|c|}
\hline \multirow{2}{*}{ Classification } & \multicolumn{3}{|c|}{ Memale } & \multicolumn{3}{c|}{ Male } \\
\cline { 2 - 8 } & Under middle & High school & College over & Under middle & High school & College over \\
\hline 1985 & 39.5 & 42.1 & 46.3 & 61.1 & 77.1 & 93.5 \\
\hline 1990 & 45.6 & 47.5 & 53.1 & 63.2 & 80.0 & 93.2 \\
\hline 1995 & 44.6 & 50.2 & 57.9 & 62.3 & 81.2 & 93.9 \\
\hline 1997 & 44,4 & 52.0 & 61.0 & 60.5 & 81.0 & 91.8 \\
\hline 1998 & 42.4 & 48.4 & 56.7 & 58.4 & 80.0 & 90.6 \\
\hline 2004 & 46.6 & 53.1 & 60.1 & 52.5 & 77.9 & 87.8 \\
\hline 2006 & 39.8 & 53.1 & 64.4 & 50.8 & 76.9 & 89.0 \\
\hline Changes & 0.3 & 11.0 & 18.1 & -7.8 & -0.2 & -4.5 \\
$(1985-2006)$ & & & & & \\
\hline
\end{tabular}

Source: NSO (Various Years).

The proportion of labor force participation of Korean women is similar to that of women in many industrialized countries. As of 2005, 62.0 percent of all women (15 years of age and older) were participating in the paid economy. This figure is somewhat lower than the comparable figures in the United States and some European countries, such as Sweden, but similar to figures in other countries, such as Germany and France (OECD, 2005). The majority of employed women (more than $60 \%$ ) hold full-time jobs.

Recently, labor force participation rates of women rose in most of the industrialized countries, continuing longer-term though less apparent trends. These trends are due mainly to the growth of labor force participation of married women. The total participation rate for women in the labor force is lower than that of the U.S., Canada, and Japan (See <Table 7>). During the 1990-2003, one of the remarkable changes was the sharply increasing female labor force participation rates from 52.4 percent to 68.4 percent in Nederland, while the female labor force participation rates decreased from 36.0 percent to 28.1 percent in Turkey.

Table 7: Trends of Labor Force Participation in OECD Countries (15-64)

(Unit: percent)

\begin{tabular}{|c|c|c|c|c|c|c|c|}
\hline Country & $\mathbf{1 9 9 0}$ & $\mathbf{2 0 0 3}$ & Increasing rate & Country & $\mathbf{1 9 9 0}$ & $\mathbf{2 0 0 3}$ & Increasing rate \\
\hline Sweden & 82.5 & 76.9 & -5.6 & Japan & 57.1 & 59.9 & 2.8 \\
\hline Denmark & 77.6 & 74.8 & -2.8 & Germany & 55.5 & 64.5 & 9.0 \\
\hline Finland & 73.5 & 72.1 & -1.4 & Nederland & 52.4 & 68.4 & 16.0 \\
\hline Norway & 70.7 & 75.9 & 5.2 & Korea & 49.9 & 52.8 & 2.9 \\
\hline Canada & 68.3 & 73.0 & 4.7 & Belgium & 46.1 & 55.8 & 9.7 \\
\hline Switzerland & 68.2 & 73.9 & 5.7 & Italy & 44.0 & 48.3 & 4.3 \\
\hline U. S. A & 67.8 & 69.7 & 1.9 & Island & 42.6 & 57.6 & 15.0 \\
\hline U. K & 67.3 & 69.2 & 1.9 & Greece & 42.6 & 51.0 & 8.4 \\
\hline New Zealand & 63.2 & 69.3 & 6.1 & Spain & 42.2 & 55.7 & 13.5 \\
\hline Australia & 61.5 & 66.0 & 4.5 & Turkey & 36.0 & 28.1 & -7.9 \\
\hline France & 57.2 & 62.5 & 5.3 & Mexico & 35.7 & 40.5 & 4.8 \\
\hline
\end{tabular}

Source: OECD (2004), Employment Outlook. 


\section{CONCLUSIONS}

Korea has achieved remarkable economic growth and arisen the knowledge-based society. There has been both considerable increase of female labor participation rate and a considerable decrease of the fertility rate in Korea. Korea's total fertility rate decreased from 2.83 per fertile woman in 1980 to 1.13 per fertile in 2006 . The female labor force participation increased 42.8 percent in 1980 to 50.3 percent in 2006 . The reduction of fertility would harm the growth of potential GDP in the long run. The decline in fertility may has beneficial effects on long-run economic growth by allowing greater investment in children health and education. Because fertility and female labor force participation are determine in the complex decision, they are both analyzed by using on various aggregate data in this paper.

Women's employment emerges as one of the main determinants of fertility in Korea. Fertility is negatively related to labor force participation, especially in gainful employment. In general, fertility stands as a critical factor in women's efforts to improve their labor forces. While female labor force participation increases in labor market, its effects are more significant in relation to occupational status and earnings. Researchers have attempted to identify the increase in female employment that can be explained by declining fertility. Our analyses suggest otherwise, as the Korea case study is actually close to the simple correlation between fertility and labor supply. Likewise, many researchers have suggested that fertility is negatively correlated among child factor, income factor, social and workplace factor, and social value factor in Korea.

Women's participation in the labor force continues to move closer and closer to the pattern shown by men, and occupational choices have also become more similar to men's. However, women still retain primary responsibility for housework and childcare in most Korean families. This pattern has been changing as families respond to rising labor market opportunities for women that increase the opportunity cost of such arrangements. In recent years, however, a growing number of young mothers have maintained continuous labor market activity, either by maintaining the jobs they held before giving birth or by shifting into part-time employment. The periodic separation of women from work is seen by proponents of human capital theory as the major determinant of the gender wage gap and occupational sex segregation in Korea. Further, the policy toward the lower fertility in Korea should encourage female participation in the labor market.

\section{AUTHOR INFORMATION}

Nam Chul Lee received his Ph.D. in Economics at the University of Oklahoma, U.S.A. He is presently a research fellow at the Korea Research Institute for Vocational Education and Training (KRIVET. His research interests include economic development, labor market analysis, and human resource development. He has published numerous articles in professional journals, such as Journal of Applied Business and Economics, Journal of International Economic Studies, Journal of American Academy Business, Cambridge, and East Asian Review, etc.

Dr. Ji-Sun CHUNG is a research fellow of Korea Research Institute for Vocational Education and Training (KRIVET). She received her Ph. D. in Sociology of Education from the University of Toronto. She also worked on the Comparative and International Development Education Program, University of Minnesota as a visiting scholar researching and lecturing. Her writings are mostly in the fields of participation rates of adult education, postsecondary vocational education and human resources development of disadvantaged Groups.

\section{REFERENCES}

1. Ahn N and Mira, P (2002), "A Note of the Relationship between Fertility and Female Employment Rates in Developed Countries, Journal of the Population Economics 15(4), PP. 667-682.

2. Andersen, G (1999), Social Foundations of Postindustrial Economies, Oxford, New York, Oxford University Press.

3. Bank of Korea (Various Years). National Income Accounts, Seoul, Korea. 
4. Becker, G. S (1965), Human Capital: A Theoretical Analysis with Special Reference to Education, Columbia University Press, New York.

5. Becker, G.S, and Lewis, G.H (1974), Interrelation Between Quantity and Quality of Children, in T.W, Schultz (eds), Economics of the Family: Marriage, Children and Human Capital, PP. 81-90, Chicago, University of Chicago Press.

6. Bergmann, B (1986), The Economic Emergence of Women, New York, Free Press.

7. Cho. Y (2006). Married Female Birth and Labor Supply: Life Cycle Model. KDI Policy Research Series 2006-01. (Korean).

8. Duffy, A and Morene, P (1992), The Part-time Paradox: Connecting Gender, Work and Family, Toronto, McClelland \& Stewars.

9. Easterlin, R and Crimmins, E (1985), The Fertility Revolution: A Supply-Demand Analysis, Chicago, University of Chicago Press.

10. Howard H (1986), "Rise in Mother Labor Force Activity includes those with Infants," Monthly Labor Review, February, PP. 43-45.

11. Kim, H (2006), Tax and Public Finance Policy for Long-term Human Capital Formation: An Economic Analyzes about the Factor Birth Rate Resolution, Korea Institute of Public Finance, (Korean).

12. Korea Research Institute for Vocational Education \& Training (Various Years), Vocational Education and Training Indicators in Korea, Seoul, Korea (Korean).

13. Lee, N. C (1999), "Trends in the Female Labor Market of South Korea since 1970," East Asian review 3, PP. 41-57.

14. (2000), "Education and Economic Growth in Korea, 1966-1997," Journal of Applied Business Research 16(4), PP. 24-38.

15. Lee. S (2005). Reason of Low Birth Rate and Comprehensive Policy Research, RR 2005-30(2), Presidential Committee on Ageing Society and Population Policy (Korean).

16. Mammen, K. and Paxson. C (2000), "Women's Work and Economic Development," Journal of Economic Perspective 14(4), PP. 141-164.

17. Meulders, D., Plasman, O., Plasman, R (1994), Atypical Employment in the EC, Aldershot Dartmouth.

18. Mincer, J (1962), On-the Job-Training: Costs, Returns and Some Implications," Journal of Political Economy 70, PP. 50-79.

19. Ministry of Education (various years), Educational Indicators in Korea, Seoul, Korea (Korean).

20. Ministry of Labor (various years), Survey Report on Wage Structure, Seoul, Korea (Korean).

21.

22. National Statistic Office (various years), Annual Report on the Vital Statistics, Daejeon, Korea (Korean). $\overline{\text { Daejeon, Korea (Korean). }}$ (various years), Annual Report on the Economically Active Population Survey,

23. OECD (2003), ICT and Economic Growth Evidence from OECD Countries, Industries and Firms, Paris.

24. OECD (Various Years), Education at a Glance, Paris.

25. OECD (Various Years), Employment Outlook, Paris.

26. OECD (1996). Employment and Growth in the Knowledge-based Economy, Paris.

27. Park. S. I and Park, H. K (1984), The Wage Structure of Korea, Research Series, No. 54, Seoul, KDI (Korean).

28. Todaro, M. P (1996), Economic Development, Addison Wesley.

29. Sam Sung Economic Research Institute (2005), An Analyses of Low Fertility Reasons after IMF.

30. Shapiro, D and Shaw, L. (1983), "Growth in the Labor Force Attachment of Married Women: Accounting for Changes in the 1970s", Southern Economic Journal, 50(1), PP. 461-73

31. Thomas J and F. Stafford (1991), "The Allocation of Time, " Journal of Economic Literature 29:, PP. 3-26.

32. U.N (1996, 2006), World Population Prospects.

33. Willis, R. J (1973) "A New Approach to the Economic Theory of Fertility Behavior," Journal of Political Economy, 81, PP, S14-64.

34. World Bank (2003), World Development Report 2003, The World Bank, Oxford University Press.

35. Zabel, J. E (1993), "The Relationship Between Hours of Work and Labor Force Participation in Four Models of Labor Supply Behavior," Journal of Labor Economics 11, PP. 387-416. 
NOTES 